\title{
Desain Hijau: Pemanfaatan Limbah Kayu Jati untuk Desain Furnitur Naratif dengan Aplikasi Finis Ramah Lingkungan
}

\author{
July Hidayat ${ }^{1}$, Rudy Pramono ${ }^{2}$ \\ Universitas Pelita Harapan \\ july.hidayat@uph.edu
}

\begin{abstract}
Furnitur kayu jati memiliki nilai estetis dan potensi ekonomi dalam perdagangan nasional atau pun global karena memiliki durabilitas dan nilai estetis yang tinggi. Namun dominasi penggunaan kayu solid berpotensi merusak lingkungan, dan aplikasi bahan finis yang mengandung formalin (formaldehyde), isosianat, logam berat, dan VOC (Volatile Organic Compound) berpotensi merusak kesehatan aplikator serta pengguna. Salah satu upaya untuk mewujudkan desain hijau furnitur kayu jati adalah memanfaatkan limbah, berupa kayu bekas dan ranting-ranting kayu, dengan finis yang aman untuk kesehatan manusia. Di lain pihak, desain yang berorientasi pada pemenuhan kompleksitas kebutuhan manusia dan ramah lingkungan sudah menjadi standar kualifikasi keprofesian desain interior yang ditetapkan oleh CIDA dan kerap menjadi persyaratan kesepakatan perdagangan regional (terutama untuk desain hijau). Pendekatan desain naratif dengan strategi desain multi-sensori adalah bagian orientasi desain ini. Penelitian memakai metode studi kasus dengan teori desain multi-sensori. Hasil penelitian adalah implementasi teori tersebut dalam desain furniture, untuk memberikan nilai tambah, ketika desain furnitur bukan sekadar objek pengakomodir aktivitas tetapi media untuk memberikan pengalaman kepada pengguna.
\end{abstract}

Kata kunci: desain ramah lingkungan, furnitur naratif

\section{PENDAHULUAN}

Furnitur kayu jati memiliki nilai estetis dan potensi ekonomi yang tinggi karena memiliki serat kayu yang indah dan tahan lama. Gambaran tentang potensi ekonomi furnitur kayu dinyatakan oleh Direktur Jenderal Industri Kecil dan Menengah (IKM) Kementrian Perindustrian Republik Indonesia, Gati Wibawaningsih. Beliau menyatakan bahwa dari periode Januari sampai Oktober 2018, nilai ekspor furnitur dan kerajinan kayu nasional mencapai 1,4 miliar dollar Amerika Serikat (Kompas, 30 November 2018). Walaupun memiliki potensi ekonomi yang tinggi, ada kalanya, penetrasi pasar kerajinan furnitur kayu jati dari pengrajin lokal terhadap pasar lokal terbatas dan belum bisa menembus pasar ekspor. Dari sudut pandang desain, berdasarkan pengamatan di lapangan, masalah ini minimum disebabkan oleh tiga hal sebagai berikut: (1) kreativitas dan inovasi desain masih terbatas karena pengrajin cenderung mengikuti pola desain yang sudah ada, (2) kualitas furnitur yang dihasilkan, terkait kehalusan, kerapihan, kualitas finis, keamanan dan kenyamanan pengguna belum optimal, karena material finis mengandung formalin, atau isosianat, atau logam berat, atau VOC dalam kadar yang tinggi sehingga tidak sehat untuk pengguna dan otomatis tidak memenuhi standar ekspor, (3) konsep desain tidak terkomunikasikan dalam konsep pemasaran karena kerap memang desain yang dibuat tidak memiliki konsep khusus, 
karena hanya membuat produk pesanan dari pembeli atau mengikuti gaya produk yang laku di pasaran. Untuk itu ada peluang untuk menambah nilai pada desain furnitur dengan membuat desain yang ramah lingkungan, dengan memanfaatkan limbah kayu jati dan mengaplikasikan bahan finis yang juga tidak merusak lingkungan dan tidak berbahaya untuk kesehatan pengguna. Dari sudut pandang desain, hal ini sesuai dengan standar keprofesian desain interior yang ditetapkan oleh CIDA (Council of Interior Design Accreditation) bahwa seleksi material dan produk harus memperhatikan kesehatan pengguna dan tidak merusak lingkungan (CIDA, https://accredit-id.org/professionalstandards/, diakses Maret 2019). Kesepakatan perdagangan internasional, seperti yang dikemukakan oleh OECD (Organization for Economic Co-operation and Development), juga mengedepankan tuntutan terhadap efisiensi sumber daya, pemanfaatan ulang (reuse), daur-ulang (recycle), dan desain yang tidak merusak lingkungan (green design) (OECD, www.oecd.org/environment/, diakses Maret 2019).

Studi sebelumnya tentang industri atau kerajinan furnitur kayu di Indonesia antara lain dilakukan oleh: (1) Agus Sachari yang membahas gaya desain furnitur dalam artikel jurnal yang berjudul "Pergeseran Gaya oada
Desain Furnitur Indonesia Abad Ke-20" (Sachari, 2006), (2) Ibrahim Hermawan melalui artikel jurnal berjudul "Tinjauan Bentuk dan Konstruksi Mebel Jepara" yang membahas tentang bentuk, konstruksi, ergonomi dan estetika furnitur kayu Jepara (Hermawan 2013), (3) Arianti Ayu Puspita dalam kajiannya tentang "Dinamika Budaya Material pada Desain Furnitur Kayu di Indonesia" yang membahas tentang pengaruh tuntutan antisipasi masalah ekologi, perubahan kondisi sosial, ekonomi, dan gaya hidup masyarakat terhadap desain furnitur (Puspita, 2016). Kebaruan studi desain furnitur kali ini terletak pada implementasi pendekatan desain naratif dalam desain furnitur pemanfaatan limbah kayu jati yang menekankan keberadaan furnitur bukan sekadar sebagai objek untuk mewadahi aktivitas pengguna, tetapi lebih sebagai media untuk menciptakan pengalaman untuk pengguna, dengan cara merangsang berbagai indera pengguna, ketika mengalami desain. Pendekatan narasi adalah metode untuk mempertanyakan dan menganalisis informasi yang memiliki bentuk dan protokol (tata alur penyampaian informasi) dalam sebuah cerita (Dohr, 2011:29).

Terkait dengan standar keprofesian untuk membuat desain yang tidak merusak lingkungan dan orientasi desain saat ini yang 
sudah tidak bertujuan untuk sekadar membuat furnitur sebagai produk (object centered design), tetapi untuk menciptakan pengalaman pengguna tersebut, pertanyaan penelitian yang menjadi acuan perencanaan desain furnitur adalah, bagaimana membuat desain furnitur yang ramah lingkungan dengan pendekatan desain naratif, yang juga disertai dengan aplikasi teknologi finis yang ramah lingkungan.

Untuk menyajikan ilustrasi terhadap implementasi pendekatan desain naratif, penelitian mempergunakan metode studi kasus, dan sebagai kasus studi dipilih pengrajin limbah kayu jati di Desa Serenan. Desa Serenan adalah desa pengrajin furnitur kayu jati. Pada umumnya furnitur yang dibuat mengikuti pola desain bergaya klasik Eropa atau tradisional Jawa, tetapi sekelompok kecil pengrajin mencoba untuk membuat furnitur ramah lingkungan dengan mengolah limbah kayu jati. Selama ini, karya desain yang dihasilkan lebih kepada pemanfaatan kayu sisa bongkaran atau kayu bekas yang memiliki tekstur unik, untuk membuat furnitur yang tampak kuno (antik) atau lama atau usang, karena memiliki tekstur kayu kasar dan berlubang-lubang. Desain yang dihasilkan lebih berorientasi untuk menghasilkan objek desain, bukan untuk memberikan pengalaman kepada pengguna. Atas latar-belakang ini, pengrajin pengolahan limbah kayu jati di Desa Serenan dipilih untuk menjadi kasus studi inovasi desain dengan cara mengimplementasikan pendekatan desain furnitur naratif dengan metode desain multi-sensori. Model Studi Kasus Robert K. Yin dipilih karena model Yin didahului oleh eksplorasi atau pengembangan teori dan dalam hal ini, kasus studi di Serenan adalah ilustrasi penerapan teori pendekatan desain naratif dengan strategi desain multi-sensori dalam desain furnitur untuk inovasi desain furnitur (karena kondisi sebelumnya, seperti yang sudah dijelaskan, desain furnitur yang dihasilkan di Serenan, sekadar berorientasi pada objek, bukan untuk memberikan pengalaman kepada pengguna).

Tujuan dari studi ini adalah untuk memahami strategi memanfaatkan limbah sebagai bagian dari usaha membuat desain ramah lingkungan, memahami pendekatan desain naratif dengan kasus studi desain furnitur, dan memahami aplikasi material finish kayu berbasis air yang ramah lingkungan.

\section{METODE}

Penelitian studi kasus didahului oleh tahapan pengembangan teori, pemilihan studi kasus, analisis studi kasus, analisis kesimpulan, modifikasi teori dan memberikan rekomendasi implikasi kebijakan (adaptasi 
model studi kasus Robert K. Yin) (Yin, 1994:49). Strategi desain naratif yang dipakai dalam studi desain furnitur ini adalah desain multi-sensori. Desain multi-sensori akan menciptakan pengalaman yang utuh dari pengguna desain karena persepsi pengguna dihasilkan oleh integrasi berbagai indera. Menurut Juhani Pallasmaa, desain sensoris dihasilkan oleh tujuh indera, yaitu (1) penglihatan, (2) pendengaran, (3) penciuman, (4) perabaan, (5) perasa, (6) gerak dan (7) prekonsepsi atau identifikasi menubuh (Pallasmaa, 2016). Sebelumnya MerleauPonty sudah menteorikan terlebih dahulu tentang persepsi menubuh (bodily-perception) sebagai hasil dari penggunaan pendekatan fenomenologi ketika mengalami sebuah karya seni (termasuk ketika mempersepsi karya desain). Dengan demikian, teori yang dikembangkan di sini untuk melakukan tahapan pertama dalam metode penelitian studi kasus adalah teori desain sensoris dari Juhani Pallasmaa dan strategi desain hijau tentang pengurangan limbah (reduce), pemanfaatan limbah (reuse), dan daur ulang limbah (recycle). Kasus yang dipilih adalah kerajinan pemanfaatan limbah kayu jati di Desa Serenan.

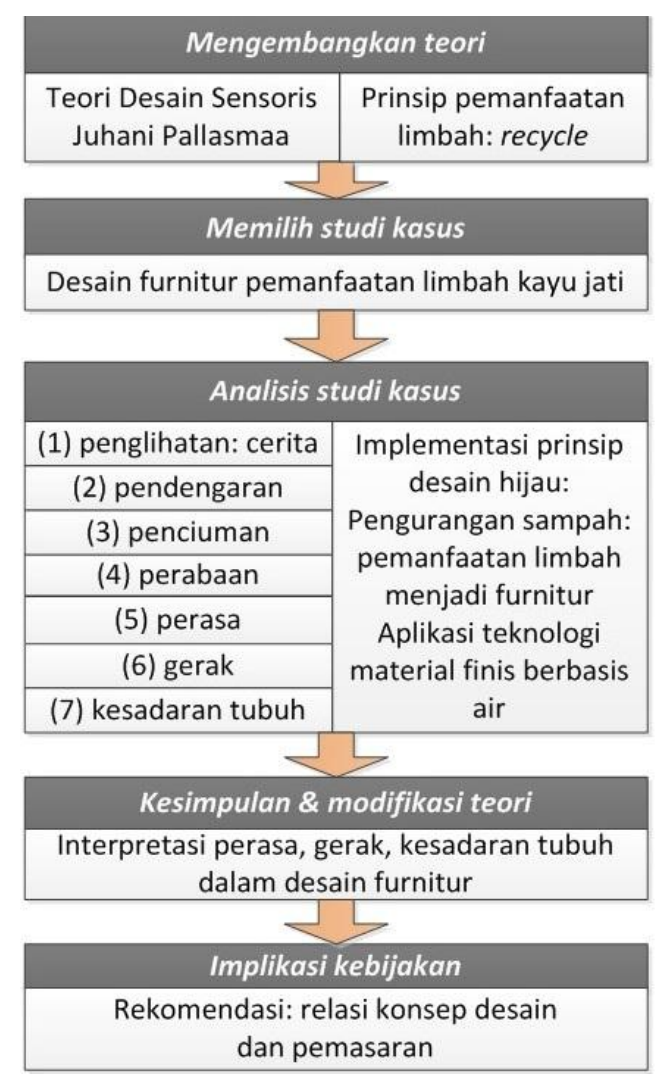

Gambar 1. Metode Penelitian Studi Kasus Sumber bagan: Adaptasi Model Penelitian Studi Kasus Robert K. Yin (Yin, 1994:49)

Hasil analisis adalah impelementasi kombinasi pendekatan desain hijau dan naratif pada desain furnitur pemanfaatan limbah kayu jati (lihat gambar 1 tentang implementasi metode studi kasus dalam penelitian ini).

\section{HASIL DAN PEMBAHASAN}

A. Desain Multi-sensori sebagai Strategi Pendekatan Desain Naratif untuk Menciptakan Pengalaman bagi Pengguna

Naratologi adalah sebuah kelompok teori narasi, teks narasi, imaji, pertunjukan, peristiwa, dan artefak budaya yang menyampaikan sebuah cerita, ketika antara 
satu teori dengan lainnya, tidak dipahami secara individual, tetapi dalam relasi satu dengan lainnya secara keseluruhan, seperti sebuah ensambel (Bal, 2009:3). Desain adalah bahasa visual atau imaji. Desain naratif adalah desain yang strategi penyampaian maknanya dilakukan dengan cara bercerita, untuk menciptakan pengalaman bagi pengguna desain. Untuk itu, desain multi-sensori adalah salah satu strategi dari desain naratif, untuk menciptakan pengalaman yang lebih utuh, melalui kombinasi stimulus berbagai indera.

Juhani Pallasmaa dalam buku Eye of The Skin (1996) mempublikasikan adanya tujuh indera ketika melakukan persepsi, yaitu lima indera yang biasa kita kenal, seperti penglihatan, pendengaran, penciuman, perabaan dan perasa, tetapi kemudian ditambah tulang dan otot, untuk menciptakan gerak dan kesadaran tentang skala, proporsi, dan keseimbangan. Ketika menulis tentang pendekatan fenomenologi dalam arsitektur, yaitu arsitektur tujuh indera (Holl, 2007), Juhani Pallasmaa mengembangkan tujuh indera tersebut menjadi (1) penglihatan, (2) pendengaran, (3) penciuman, (4) perabaan, (5) perasa, (6) gerak (otot dan tulang dijadikan 1 indera), dan (7) kesadaran tubuh (menubuh) sebagai sebuh kesatuan. Dalam hal ini, Pallasmaa kiranya mendapat pengaruh dari M. Merleau-Ponty, yang sudah jauh lebih awal menulis tentang persepsi tubuh (menubuh), karena persepsi terhadap sebuah objek, persepsi terhadap ruang dan keruangan objek, bukan merupakan hal yang terpisah (Ayer, 1962:148); sama halnya dengan persepsi satu indera dengan lainnya menyatu dalam persepsi tubuh secara keseluruhan. Di dalam kesadaran tubuh (menubuh), terjadi terjadi integrasi antara pikiran, rasa, penglihatan, pendengaran, penciuman, perabaan, perasa, dan gerak, ketika semua indera tersebut menjadi "pepanjangan atau ekstensi" dari pikiran dan rasa, sama halnya seperti seorang kaligrafer membuat karya seni kaligrafi; gerakan sang ahli ketika membuat sapuan kuas menjadi satu kesatuan sistem dengan pikiran dan rasa yang ia miliki. Dalam konteks desain furnitur naratif, persepsi melihat, mendengarkan, membaui, meraba tekstur, merasakan selera atau orientasi desain, bergerak memakai furnitur dan mencerap cerita yang dibawa oleh tema desain furnitur adalah sebuah kesatuan pengalaman.

B. Prinsip Desain Hijau dalam Pengelolaan Limbah: Konservasi Energi melalui, dan Seleksi Material dalam Desain Daur Ulang

Kayu memiliki sifat fleksibel dalam pengertian serba guna sehingga mudah untuk didaur ulang. Potongan-potongan kayu yang tidak 
terpakai sebagai limbah produksi furnitur dapat dimanfaatkan untuk membuat particleboard. Strategi daur ulang membuat umur penggunaan produk kayu diperpanjang, sehingga terjadi penghematan energi karena kebutuhan akan produk baru hilang dan energi yang dikeluarkan lebih kecil dibandingkan energi yang dibutuhkan untuk mengolah material kayu dari awal. Kayu dinyatakan bersifat serba guna karena kalau pun kayu tidak bisa didaur ulang, sampah kayu masih bisa diolah menjadi energi biomassa untuk bahan bakar atau tenaga listrik.

Aplikasi teknologi material finis yang ramah lingkungan adalah pembuatan material finis yang berbasis air. Material finishing kayu yang umum dipergunakan antara lain adalah melamine yang mengandung formaldehyde (formalin), yang bersifat karsinogenik. Kadar formaldehyde di udara lebih dari $0,37 \mathrm{mg} / \mathrm{m} 3$ berbahaya untuk kesehatan (Badan Standarisasi Nasional) dapat menyebabkan mata berair, sensasi pedas di mata, panas atau kering di hidung dan tenggorokan, dan iritasi kulit. Zat terlarut bahan kimia lain dalam material finis yang berbahaya untuk kesehatan pengguna adalah isocyanate (isosianata) yang ada dalam material finis kayu polyurethane (PU).
Ketika menerapkan prinsip desain hijau, kita memakai material finis yang lebih ramah lingkungan, yaitu material finis yang berbahan dasar air (water-based). Material finis ini tetap mengandung partikel PU ataupun resin akrilik, tetapi PU atau resin akrilik tersebut dilarutkan dalam pelarut dengan kadar VOC (Volatile Organic Compound) rendah, sehingga formaldehyde atau pun isocyanate yang disemprotkan ke udara selama proses pengeringan cat, di bawah kadar yang berbahaya untuk kesehatan manusia.

\section{Kasus Desain Furnitur Daur Ulang memakai Pendekatan Naratif}

Kasus desain furnitur yang diambil adalah pembuatan furnitur dari limbah kayu jati, berupa ranting-ranting kayu yang tidak terpakai dalam pembuatan furnitur pada umumnya dan potongan-potongan kayu bekas (lihat gambar 2A dan 2B). Rantingranting kayu tersebut dimanfaatkan untuk membuat kursi dan meja yang basis desainnya adalah struktur ranting kayu (lihat gambar $3 \mathrm{~A}$ dan 3B).

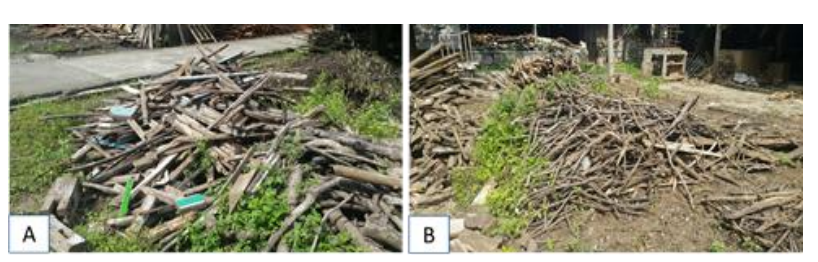

Gambar 2A dan 2B. Ranting-ranting kayu jati dan potonganpotongan kayu bekas di kompleks bengkel pembuatan kerajinan furnitur dari kayu bekas di Desa Serenan, Klaten. Sumber gambar: Hidayat, 2019. 
Permukaan meja dibuat dari sisa-sisa pecahan atau potongan marmer dari pabrik marmer. Biasanya pecahan atau potongan marmer tersebut didaur ulang oleh pihak pabrik untuk membuat ubin marmer daur ulang, tetapi sebagai alternatif, pecahan marmer tersebut dapat dimanfaatkan untuk membuat bidang bergambar yang menyampaikan sebuah cerita (lihat gambar 3D). Dudukan kursi dibuat dari rumput asli 'moss' yang memiliki daya tahan untuk tumbuh di tengah kondisi minimum karena yang dibutuhkan untuk tumbuh hanya kelembaban (lihat gambar 3B). Rumput 'moss' dapat menyerap kelembaban ketika kelembaban di dalam ruang lebih dari 17 gram/meter kubik dan menambah kelembaban ketika kelembaban ruang kurang dari 12 gram/meter kubik.

Konsep bentuk desain furnitur tersebut adalah pohon yang tumbuh dalam ruang alam, ketika elemen akar, batang, ranting dan daun pohon hadir bersama bidang rumput, burung dan kupu-kupu yang hinggap di dahan pohon. Bagian kaki meja dan kursi mengilustrasikan akar dan dahan, bagian bidang permukaan meja mengilustrasikan daun-daun pohon (musim gugur), termasuk binatang-binatang seperti burung dan kupu-kupu yang hinggap di atas pohon. Daun dan binatang-binatan yang hinggap di ranting pohon juga diwujudkan secara tiga dimensi dan diposisikan di sela-sela ranting pada bagian kaki meja. Bagian dudukan furnitur mengilustrasikan bidang rumput.

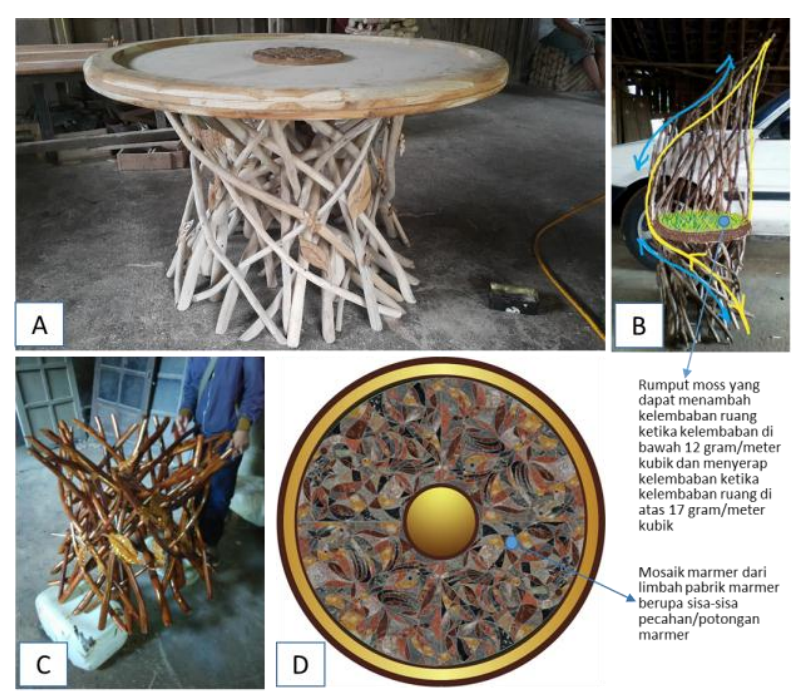

Gambar 3A, 3B, 3C, 3D. Struktur Kaki Meja memakai Limbah Ranting Kayu (3A), Struktur Sandaran dan Kaki Kursi memakai Ranting Kayu (3B), Aplikasi Material Finis (3C), Imaji Permukaan Meja dari Limbah Pabrik Marmer berupa Sisa Potongan/Pecahan Marmer. Sumber gambar: Hidayat, 2018.

Aplikasi strategi desain multi-sensori pada desain furnitur ini adalah sebagai berikut: pertama, stimulasi penglihatan diberikan melalui tema alam yang diwujudkan melalui komposisi meja dan kursi. Komposisi bentuk dan warna limbah ranting kayu dan marmer pada meja dimaksudkan untuk mengilustrasikan pohon dan komposisi bentuk dan warna limbah ranting dan rumput 'moss' pada kursi dimaksudkan untuk mengilustrasikan bidang rumput dan rantingranting pohon. Kedua, stimulasi penciuman diberikan melalui bau rumput hidup pada bidang dudukan kursi. Stimulasi penciuman juga dapat diberikan ketika elemen dekoratif berupa ukiran daun, bunga dan burungburung kecil pada dahan kayu dan tengah 
meja dibuat dari kayu cendana yang mengeluarkan bau wangi. Ketiga, stimulasi pendengaran dapat diberikan melalui musik instrumental dari radio kecil dengan baterai yang bisa disembunyikan di sela-sela ranting kayu pada kaki meja dan bunyi gemerisik rumput ketika menggeser posisi pada bidang dudukan kursi. Keempat, stimulasi perabaan diberikan oleh tekstur perrmukaan kayu, rumput, dan batu marmer. Kelima, stimulasi perasa yang oleh Pallasmaa diinterpretasi sebagai selera arsitektur, pada desain furnitur pemanfaatan limbah ini terkait dengan selera gaya hidup kembali ke alam yang antara lain memakai furnitur dari material, warna dan tekstur natural dengan material finis berbasis air. Keenam, stimulasi indera gerak diberikan melalui ilusi "liukan" gerak ranting pada kaki meja dan kursi, serta ilusi “liukan” gerak daun pada elemen dekoratif ranting kaki meja. Ketujuh, kesadaran diri yang bersifat propriosepsi (persepsi bawah sadar, terutama dari saraf sensorik otot, sendi, dan vestibular atau alat keseimbangan). Keberadaan indera refleks ini membuat pengguna berbadan gemuk tidak mau duduk di kursi karena menganggap kursi terlalu ringkih atau tidak seimbang, walaupun belum mendudukinya. Stimulasi refleks antara lain timbul ketika bagian sandaran kursi dibuat melengkung sehingga menciptakan semacam relung. Gerakan refleks yang dapat terjadi ketika orang duduk di kursi bersandaran lengkung adalah menyandarkan tubuhnya pada relung sandaran tersebut. Untuk itu, pada bagian sandaran kursi, di sela-sela ranting kayu, perlu diisi dengan bantalan dari limbah kain perca misalnya, agar bagian sandaran tidak melukai bagian belakang tubuh pengguna. Adanya gerakan refleks ini disebabkan karena manusia memiliki imajinasi dan memori yang dipengaruhi oleh akumulasi pengalaman dan kumpulan imaji dalam benak pemikiran manusia.

\section{SIMPULAN}

Ketika desain furnitur dibuat dengan pendekatan desain hijau atau desain yang ramah lingkungan, dengan strategi konservasi energi berupa pemanfaatan limbah dan aplikasi teknologi material finis berbasis air, hal tersebut bukan merupakan pilihan tetapi standar keprofesian desainer interior dan kesepakatan perdagangan internasional untuk menjual produk yang tidak merusak lingkungan. Ketika desain furnitur dibuat dengan pendekatan desain naratif, orientasi atau fokus desain bergeser dari objek ke pengguna. Ketika dibuat dengan pendekatan desain naratif, pengguna mendapatkan pengalaman memaknai desain furnitur lebih dari sekadar fungsi guna, tetapi juga mencerap pesan cerita yang diwujudkan oleh 
elemen visual desain furnitur tersebut, dalam kasus ini, adalah cerita bagaimana sebuah furnitur kayu berasal dari kayu yang tumbuh dalam ruang alam. Ketika pengguna memakai kursi, makna yang diharapkan untuk ditemukan adalah bukan sekadar duduk di kursi, tetapi duduk di alam, di atas rumput, bersandar dalam relung yang dibentuk oleh ranting-ranting pohon; kembali ke alam. Implikasi dari penciptaan pengalaman ketika memakai furnitur adalah penceritaan kembali dari pengguna satu ke calon pengguna lainnya dan penceritaan kembali adalah kekuatan dari narasi.

Modifikasi teori yang dihasilkan adalah ketika indera perasa diterjemahkan ke dalam desain furnitur. Hal ini sudah dikemukakan oleh Pallasmaa ketika menterjemahkan rasa atau selera (taste) menjadi selera arsitektur. Aplikasi stimulasi indera perasa dalam desain furnitur adalah persepsi pikiran dan rasa terhadap selera atau orientasi desain hijau sebagai representasi cara hidup kembali ke alam yang dibawa oleh narasi furnitur secara keseluruhan.

Implikasi kebijakan dalam konteks studi kasus ini adalah penyatuan antara konsep desain dengan konsep pemasaran produk karena pndekatan desain ramah lingkungan dan narasi (cerita) yang dibawa oleh konsep desain furnitur dapat berperan sebagai nilai tambah dalam desain furnitur; bahwa furnitur yang dibeli dan dipakai tidak hanya memenuhi fungsi guna sebagai wadah duduk atau wadah peletakan benda tapi juga memenuhi fungsi evokasi ketika menstimulasi rasa atau emosi dengan keindahan bentuk alam yang dinamis, visualisasi warna dan perabaan tekstur kayu dan rumput hidup yang hangat, serta juga memenuhi fungsi simbol ketika penggunaan desain menjadi tanda keikutsertaan pengguna dalam gerakan cara hidup kembali ke alam dengan menciptakan ilustrasi duduk di ruang alam; desain adalah representasi nilai yang tidak terbatas pada fungsi guna.

\section{UCAPAN TERIMA KASIH}

Ucapan terima kasih diberikan kepada Universitas Pelita Harapan yang sudah memberikan biaya untuk pelaksanaan proyek pengabdian kepada masyarakat.

\section{DAFTAR PUSTAKA}

Ayer, A.J. (Editor). 1962 (Terjemahan Bahasa Inggris). Phenomenology of Perception $M$. Merleau-Ponty, London: Routledge dan Kegan Paul Ltd.

Dohr, Joy dan Margaret Portillo. 2011. Design Thinking for Interiors, Hoboken, New Jersey: John Wiley and Sons, Inc. 
Hermawan, Ibrahim. 2013. Tinjauan Bentuk dan Konstruksi Mebel Jepara, Jurnal Elektronik Reka Jiva, Volume I Nomor 1, Bandung: Institut Teknologi Nasional.

Holl, Steven, Juhani Pallasmaa, Alberto PerezGomez. 2007. "Architecture of the Seven Senses" dalam Question of Perception: Phenomenology of Architecture, page 4049 (Edisi Kedua), San Fransisco, CA: William K. Stout Publishers.

Mike, Bal. 2009. Narratology. Introduction to the Theory of Narrative (Cetakan Ketiga), Toronto, Buffalo, dan London: University of Toronto Press.

Mackenzie, Dorothy. 1991. Green Design. Design for the Environment, London: Laurence King Ltd.

Puspita, Ariyanti Ayu. 2016. Dinamika Budaya Material pada Desain Furnitur Kayu di Indonesia, Jurnal Seni Budaya "Panggung", Volume 26 Nomor 3, Bandung: Institut Seni Budaya Indonesia.

Sachari, Agus. 2006. Pergeseran Gaya pada Desain Furnitur Indonesia Abad Ke-20, Jurnal Dimensi Interior Volume 4 Nomor 1, Surabaya: Universitas Kristen Petra.

Yin, Robert K. 1994. Case Study Research. Design and Methods, Thousand Oaks, London, dan New Delhi: Sage Publications. 